JOURNAL OF MENTAL SCIENCE, AlKIL, I923.

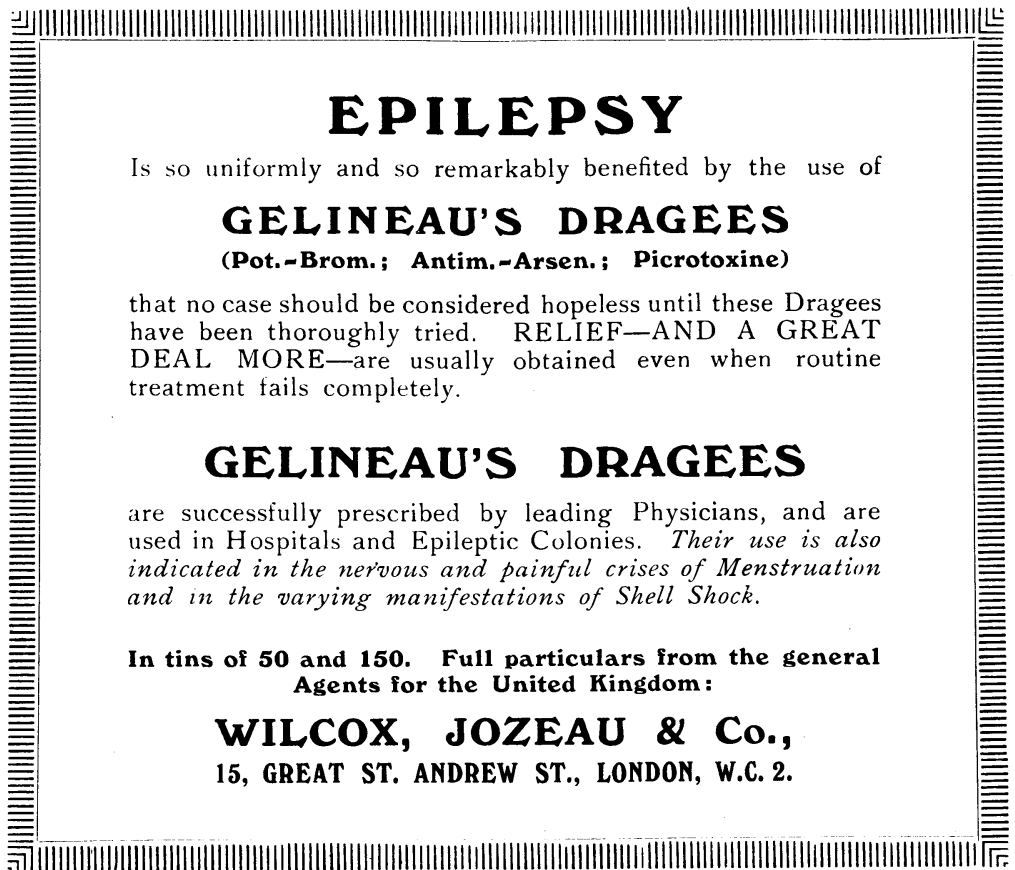

\title{
DUSTLESS ROOMS
}

On all Hospital, School, Laboratory, Library, Museum, etc., Floors and Linoleums of every description

USE

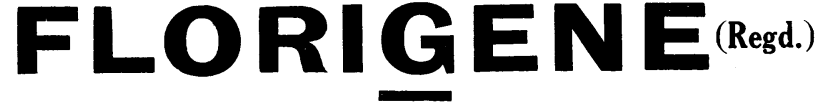

In Schools-during VACATIONS for BEST RESULTS.

It is IMPORTANT TO NOTE that ONE APPLICATION of "Florigene" ALLAYS the DUST and DIRT for 2 to 12 months according to traffic not only during each Sweeping (without Sprinkling of any kind) but also throughout all the intervening periods-which is of greater hygienic importance. "Florigene" is easily applied by unskilled.

These sanitary and labour-saving advantages are NOT attained by sweeping-powders or any other method.

Send for Particulars, Medical Reports and Testimonials to the Sole Makers-

The " DUSTIALLAMER" Co. 4, Vernon Place, Bloomsbury, London, W.C. 1.

Contractors to Admiralty, H.M. Office of Works, Colonial Govts., L.C.C., etc. 


\title{
THE INTERNATIONAL JOURNAL OF PSYCHO-ANALYSIS
}

\author{
Directed by SIGM. FREUD
}

OFFICIAL ORGAN

of the

INTERNATIONAL PSYCHO-ANALYTICAL ASSOCIATION

Edited by ERNEST JONES

President of the Association

WITH THE ASSISTANCE OF

DOUGLAS BRYAN, J. C. FLÜGEL (London)

A. A. BRILL, H. W. FRINK, C. P. OBERNDORF (New York)

NOW READY Vol. III, Parts 1, 2, 3 and 4

From the Contents of Part 1

KARL ABRAHAM: Manifestations of the Female Castration Complex.

MICHAEL JOSEPH EISLER: Pleasure in Sleep and Disturbed Capacity for Sleep.

ESTELLE. MAUDE COLE: A Few "Don'ts" for Beginners in Psycho-Analysis.

W. H. B. STODDART: A Symbolism of Appendicitis.

C. D. DALY : A Simple Lapsus Linguæ.

S. HERBERT: The Unconscious Root of Æsthetic Taste.

F. P. MULLER : A Spermatozoa Phantasy of an Epileptic.

From the Contents of Part 3

SIGM. FREUD : Dreams and Telepathy.

E. SOKOLNICKA : Analysis of an Obsessional Neurosis in a Child.

G. ROHEIM : The Significance of Stepping Over.

ERNEST JONES : Notes on Dr. Abraham's Article on the Female Castration Complex.

S. HERBERT: Three Dreams.

DOUGLAS BRYAN : A Grammatical Error
From the Contents of Part 2

J. WESTERMAN-HOLSTIJN : From the Analysis of a Patient with Cramp of the Spinal Accessory.

A. S. STRACHEY : Analysis of a Dream of Doubt and Conflict.

S. FERENCZI : The Symbolism of the Bridge.

O. PFISTER: Plato as a Forerunner of Psycho-Analysis.

S. PFEIFER : Disappointment in Love during the Analysis.

G. ROHEIM : Psycho-Analysis and the FolkTale.

S. HERBERT : A Child's Birth-Myth Story. G. ROHEIM : Ethnology and Folk-Psychology.

\section{From the Contents of Part 4}

J. VARENDONCK: A Contribution to the Study of Artistic Preference.

A. A. BRILL: Tobacco and the Individual. THEODORE SHROEDER : Pre-natal Psychisms and Mystical Pantheism.

K. ABRAHAM: Rescuing the Father and Murdering the Father in Neurotic Phantasy. ERIC HILLER: Some Remarks on Tobacco. DOUGLAS BRYAN: A Note on the Tongue.

SUBSCRIPTION 30s. or $\$ 6.00$ per Vol. of Four Parts (about 500 pp.) The Parts are not sold separately

ORdERS SHOULd BE ADdRESSED (POSTALly) TO:

\section{THE INTERNATIONAL PSYCHO-ANALYTICAL PRESS}

57, Weymouth Street, London, W. 1

OR

RICHARD G. BADGER, The Gorham Press, 194, Boylston St., Boston 17 
A Quarterly Review of Applied and General Psychology in relation to Education, PsychoAnalysis, Industry, Religion, Social and Personal Relationships, Psychical Research, \&c.

Edited by W. WHATELY SMITH, M.A.(Cantab.). Medium 8vo, wrappers, 5s. net (20s. per annum, post free).

Six quarterly issues have appeared to July, 1922. All these issues are in print, but of some no large number remains on hand. Librarians and others wishing to possess complete sets of the journal are recommended to apply for the back numbers at once.

Editorial.

$$
\text { CONTENTS OF No. } 6 .
$$

The Influence of the late W. H. Rivers.

CHAS. S. MYERS, F.R.S., D.Sc

Ethnology and Psychology. G. ELLIOT SMITH, F.R.S., M.D.

The Aims of Ethnology. The LATE W. H. R. RIVERS, F.R.S.

Responsibility v. Modern Psychology. W. BROWN, D.Sc., M.D.

The "Intelligence" of Instinct. P. GRIFFITH, M.I.C.E.

The Roots of Social Desire.

L. A. REID.

Localization of Sound in Space. RUDOLF ALLERS.

Proceedings of Psychological Section of British Association.

Foreign Intelligence.

Current Literature, etc.

KEGAN PAUL, TRENCH, TRUBNER \& Co., Ltd., Broadway House, 68-74, Carter Lane, London, E.C. 4, and 39, New Oxford Street, London, W.C. 1.

\section{BORDERLAND PATIENTS}

\section{South Beacon}

HADLOW DOWN, Nr. UCKFIELD, SUSSEX.

[Established 1892.]

Telegrams: "Hadlow Down."

Station: Buxted (L.B.\& S.C.R.)

Outdoor Occupation a Speciality.

The Usual Recreations of a Country House.

For the reception of 15 gentlemen requiring rest and quietness, but who are not ill enough for certificates.

TERMS FROM 5 GUINEAS PER WEEK.

${ }_{9}$ Fuly $_{2 / s}$ Particulars 


\title{
JOURNAL OF MENTAL SCIENCE.
}

\author{
CONTENTS FOR APRIL, 1923.
}

Original Articles.-

Pages

The Maudsley Hospital.-Lunacy Law and Institutional and Home Treatment of the Insane; by Lt.-Col. J. R. Lord, C.B.E., M.B.Edin.-The Activating Effect of Blood-serum for Cobra Venom in Mental Deficiency and other Mental Affections; by H. Ferguson Watson, M.D.Glasg., D.P.H., F.R.S.Edin.-The War-anxiety Neurotic of the Present Day: A Clinical Sketch ; by H. Somerville, B.Sc.Lond., M.R.C.S.Eng., L.R.C.P.Lond., F.C.S.Some Aspects of Sociology and their Psychiatrical Application-II; by Ian D. Suttie, M.B., F.R.F.P.\&S.Glasg.-A Study of the Endocrine-autonomic Disorders of Dementia Præcox; by W. S. Dawson, M.A., M.D., B.Ch.Oxon., M.R.C.P.Lond.-Colitis and the Normal Colon Bacilli; by Harold L. Mooney, L.R.C.P.\&S.Irel., D.P.H.

Clinical Notes and Cases.-

Observations on the Treatment of Epilepsy with Borax and Bromide; by W. J. T. Kimber, M.R.C.S.Eng., L.R.C.P.Lond.-A Case of Mental Disorder arising from Chronic Lead Poisoning; by J. F. Smyth. M.B., B.Ch. . 205-209

\section{Medico-Legal Notes.-}

Report of the Committee on Criminal Responsibility

\section{Occasional Notes.-}

The London County Council and Sir Frederick Mott, K.B.E., F.R.S.-

The Manhattan Fire: Some Reflections . . . . . . 220-226

\section{Reviews. -}

Human Character; by Hugh Elliot.-Mental Diseases: A Public Health Problem; by James V. May, M.D., with a preface by Thomas W. Salmon, M.D.-Remembering and Forgetting; by T. H. Pear, MI.A., B.Sc.-Psvchology: A Study of Mental Life; by Robert S. Woodsworth, Ph.D.-The Hidden Power; by T. Troward.-The Evolution of Knowledge; by George Shann.-The Female Impersonators; by Ralph Werther . $226-24 \mathrm{i}$

\section{Epitome of Current Literature.-}

1. Mental Hygiene.-2. Psychology.-3. Clinical Psychiatry.-4. Treatment of Insanity.-5. Pathology.-6. Sociology.-7. Mental Hospital Reports

\section{Notes and News.-}

The Medico-Psychological Association of Great Britain and Ireland: Quarterly Meeting.-South-Eastern Division.-Irish Division.-Parliamentary News.-Educational Notes.-Ministry of Health Committee on the Administration of Public Mental Hospitals (England and Wales).Election of Nurse Representatives and Nominated Members of the General Nursing Council for England and Wales, I923.- The International Congress of Mental Hygiene, 1924.- The Journal of Neurology. and Psychopathology.-The Mental After-Care Association.-MedicoPsychological Association Library.-Memorial to the late Dr. H. Hayes Newington.-Obituary.-Notices by the Registrar.-Notices of Meetings 